\title{
Impact of a prenatal education intervention in pregnant women to prevent overweight in infants
}

\author{
Rosario E. Ortiz-Félix, ${ }^{1}$ Velia M. Cárdenas-Villarreal, ${ }^{2 *}$ Patricia E. Miranda-Félix ${ }^{1}$ and \\ Milton C. Guevara-Valtier ${ }^{2}$ \\ ${ }^{1}$ Mochis Faculty of Nursing, Universidad Autónoma de Sinaloa, Sinaloa; ${ }^{2}$ Faculty of Nursing, Universidad Autónoma de Nuevo León, Nuevo León. \\ Mexico
}

\begin{abstract}
Introduction: During the first 1000 days of life is the basis for a child's future health established. Objective: To evaluate the impact of a prenatal educational intervention in pregnant women on the nutritional status of the child from birth to 4 months of age. Methods: Quasi-experimental intervention design in women with at least 12 weeks of gestation, who were randomly assigned to an intervention group (IG) to participate in five group and three individual sessions on feeding practices and maternal perception of the child's weight and signals of hunger-satiety; the control group (CG) received routine care that included at least three prenatal consultations. Results: Thirty women were included in each group. After the intervention, women in the CG practiced less exclusive breastfeeding, were more likely to underestimate or overestimate the children's weight, and perceived hunger-satiety signals with less intensity $(p<0.05) .80 \%$ of the infants in the IG had normal weight, whereas $63 \%$ of those in the CG had a combination of overweight and obesity $(p<0.05)$. Conclusions: The prenatal education program in pregnant women showed a significant effect on postnatal nutritional status of infants four months after birth.
\end{abstract}

KEY WORDS: Early intervention. Infant. Breastfeeding. Satiety response. Pregnant woman.

\section{Impacto de una intervención de educación prenatal en mujeres embarazadas para prevenir el sobrepeso en lactantes}

\section{Resumen}

Introducción: Durante los primeros 1000 días de vida se establece la base para la salud futura de un niño. Objetivo: Evaluar el impacto de una intervención educativa prenatal en mujeres embarazadas sobre el estado nutricional del hijo desde el nacimiento hasta los cuatro meses de edad. Métodos: Diseño cuasiexperimental de intervención con mujeres a partir de la semana 12 de gestación, asignadas aleatoriamente a un grupo de intervención (GI) para recibir cinco sesiones grupales y tres individuales sobre prácticas de alimentación y percepción materna del peso del hijo y de señales de hambre-saciedad; el grupo control (GC) recibió atención de rutina que incluía al menos tres consultas prenatales. Resultados: 30 mujeres conformaron cada grupo. Después de la intervención, las mujeres del GC practicaron menos lactancia materna exclusiva, fueron propensas a subestimar o sobrestimar el peso del hijo y percibieron con menor intensidad las señales de hambre-saciedad ( $p$ < 0.05). El $80 \%$ de los lactantes del Gl presentaron peso normal y $63 \%$ de los niños del GC, una combinación de sobrepeso y obesidad $(p<0.05)$. Conclusiones: El programa de educación prenatal en mujeres embarazadas mostró un efecto significativo en el estado nutricional de los lactantes después de cuatro meses del nacimiento.

PALABRAS CLAVE: Intervención temprana. Lactante. Lactancia materna. Respuesta de saciedad. Mujer embarazada.

\footnotetext{
Correspondence:

*Velia M. Cárdenas-Villarreal

E-mail: velia.cardenasvl@uanl.edu.mx

Date of reception: 06-11-2019

Date of acceptance: 07-07-2020

DOI: 10.24875/GMM.M21000529

0016-3813/O 2020 Academia Nacional de Medicina de México, A.C.. Published by Permanyer. This is an open access article under the CC BY-NC-ND license (http://creativecommons.org/licenses/by-nc-nd/4.0/).

Gac Med Mex. 2021;157:3-9 


\section{Introduction}

The prevalence of childhood obesity is increasing in many countries, with serious short- and long-term consequences. ${ }^{1}$ Mexico is no exception; moreover, it ranks among the highest places of prevalence in the world. ${ }^{2}$ Having obesity during childhood increases the probability of continuing with overweight throughout life, ${ }^{3,4}$ hence the importance of preventing it at early ages in order to fight this epidemic.

Recent studies recommend that childhood obesity preventive interventions should begin within the first 1,000 days of life, ${ }^{5}$ with the purpose to guide and train future mothers with a wellness approach, to ensure that their babies have the best start in life and that they and their families succeed in preserving a healthy weight throughout life, as well as to help alleviate the burden of non-communicable diseases in the next generations.

Reports on interventions to prevent obesity early in life recommend that modifiable variables such as gestational weight control, receptive feeding, infant feeding practices and adequate perception of the child's body weight should be considered in the perinatal period $^{6-8}$ Receptive feeding refers to the ability of parents to identify and timely respond with adequate feeding practices according to the hunger and satiety signals emitted by the child. ${ }^{6}$ Mothers with receptive feeding skills have been found to practice more exclusive breastfeeding, feeding routines and avoidance of the use of food to calm their children, unlike mothers who lack this ability. ${ }^{8-10}$

Regarding the practice of infant feeding, breastfeeding is known to protect children against obesity and to have protective effects against various chronic diseases. ${ }^{6}$ As for maternal perception of child weight status, a direct relationship with the success or failure of preventive measures against obesity has been found. ${ }^{7,11}$ When mothers correctly perceive their children's weight, they are more likely to choose healthy foods ${ }^{12}$ and to delay the introduction of supplementary feeding. ${ }^{13}$

It should be noted that most early-age obesity prevention interventions that have so far been analyzed have been carried out after the child's birth and in high-income countries. ${ }^{9-10,14-17}$ There are few interventions that have considered the pregnancy period, a stage that provides an important opportunity for future mothers to be enabled to make positive choices and learn healthy behaviors, both during pregnancy and after the baby's birth.
Specifically in Mexico, interventions to prevent and treat childhood obesity are scarce and have been focused on diet and exercise, with little or no effect. ${ }^{18}$ The purpose of this study was to evaluate the preliminary impact of an educational intervention in pregnant women focused on maternal perception of child weight status, maternal perception of hunger-satiety signals and maternal feeding practices on the nutritional status of the child four months after birth.

\section{Methods}

A quasi-experimental study was carried out, in which 80 pregnant women who attended prenatal care at two primary care institutions in northeastern Mexico, with similar sizes and demographic profiles, were recruited in the period from August to October, 2018. Twenty women were excluded because they failed to meet the eligibility criteria for the study: being older than 18 years of age, being in the first trimester of pregnancy, having a single pregnancy, and not having a diagnosis of complications of chronic diseases. The final sample was comprised of 60 participants (Fig. 1).

Random assignment of the women to the intervention (IG) and control (CG) groups was carried out using a computer program, and was informed to the participants in writing in a sealed envelope together with the study specifications. The protocol adhered to the ethical principles of the Declaration of Helsinki, ${ }^{19}$ and was approved by the Research Ethics Committee of the Mochis Faculty of Nursing, Autonomous University of Sinaloa (CEI-000-35).

The intervention program was designed based on Pender's health promotion theory, ${ }^{20}$ which describes that human behavior is a dynamic and reciprocal interaction of personal factors and cognitive and behavioral skills, which determines the taking of actions to prevent health problems. The intervention included three components: education, reinforcement of cognitive skills and postpartum follow-up (four months). The sessions and contents are described in table 1. The control group received the standard prenatal care established as a protocol in the participating health institutions (at least three follow-up visits for prenatal control and advice on diet and exercise).

A maternal-infant nurse and a nutritionist from each health institution were trained for 20 face-to-face hours, and were directly responsible for delivering the intervention, as well as two nursing graduates who collaborated in data collection. All used facilitator guidelines to provide the content of each session and 


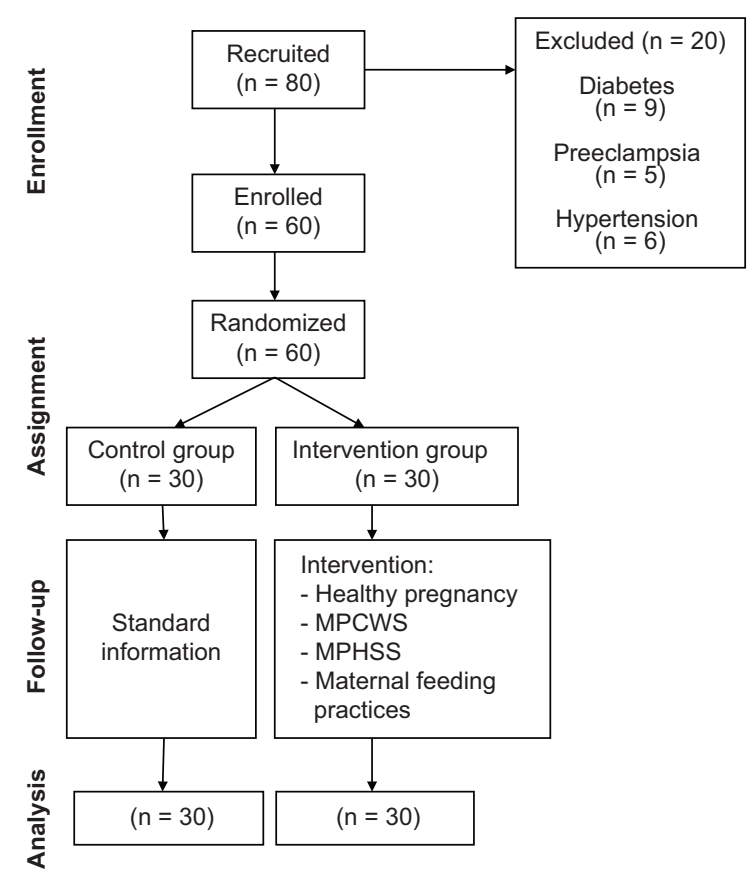

Figure 1. Study flowchart. MPCWS = maternal perception of child weight status: MPHSS = maternal perception of hunger and satiety signals.

to evaluate the process of scheduled activities during the intervention.

All participants signed the informed consent form. The group sessions were carried out with an average of eight to 10 pregnant women in an audiovisual room. and the individual sessions, in an office of the health institution. Reminders were made by means of phone calls before each prenatal control appointment.

Prior to the intervention, sociodemographic data (age, level of education, marital status, monthly income) were collected. Anthropometric measurements (weight and height) were taken during pregnancy at prenatal visits. Pre-gestational weight was self-reported by the pregnant woman; international criteria were considered for its evaluation..$^{21,22}$ The following data were collected from the child: age, gender, and birth weight and length.

The primary outcome of this study was the nutritional status of the child, which was assessed using the Z-scores of the World Health Organization growth indicator body mass index (BMI)/age, ${ }^{22}$ calculated with the Anthro program, version 3.2.2. The evaluation was carried out at four months of age of the infant.

Maternal perception of hunger and satiety signals in the infant was measured using questions adapted from the Response to Hunger and Satiety Signals
Table 1. Content of the prenatal educational intervention to prevent obesity in infants

\begin{tabular}{|c|c|c|}
\hline $\begin{array}{l}\text { Time of } \\
\text { delivery (weeks } \\
\text { of gestation) }\end{array}$ & $\begin{array}{l}\text { Educational } \\
\text { session }\end{array}$ & Content \\
\hline \multicolumn{3}{|l|}{ Group sessions* } \\
\hline Weeks 12-16 & 1 & $\begin{array}{l}\text { Healthy lifestyles during } \\
\text { pregnancy } \\
\text { - Impact of obesity on pregnancy } \\
\text { and on fetus development. } \\
\text { - Gestational weight gain } \\
\text { monitoring. }\end{array}$ \\
\hline Weeks 16-20 & 2 & $\begin{array}{l}\text { Appropriate feeding practices } \\
\text { - Exclusive breastfeeding. } \\
\text { - Breastfeeding techniques. } \\
\text { - Breast milk expression and } \\
\text { preservation methods. } \\
\text { - Breast problems }\end{array}$ \\
\hline Weeks 20-24 & 3 & $\begin{array}{l}\text { Perceptive feeding and benefits } \\
\text { - Recognition of signals of hunger } \\
\text { emitted by the child during the first } \\
\text { months of life (early, active, late) }\end{array}$ \\
\hline
\end{tabular}

Weeks 24-38 4 Recognition of signals of satiety emitted by the child at one year of life

- Main signals (early, active, late).

- Supplementary feeding

\begin{tabular}{l|l|} 
Weeks 28-32 & Adequate perception of child \\
& weight status \\
& - Infants' development stages. \\
& - Importance of weight monitoring. \\
& - Myths about obesity-health in \\
& infants. \\
& - Use of World Health Organization \\
& growth charts.
\end{tabular}

Reinforcement**

\begin{tabular}{|c|c|c|}
\hline Weeks 32-40 & $\begin{array}{l}\text { Individual } \\
\text { session } \\
1 \text { to } 3\end{array}$ & $\begin{array}{l}\text { Reinforcement of skills } \\
\text { - Demonstration of appropriate } \\
\text { feeding practices procedures. } \\
\text { - Maternal perception of hunger } \\
\text { and satiety signals. } \\
\text { - Maternal perception of child } \\
\text { weight status. }\end{array}$ \\
\hline
\end{tabular}

Follow-up

From birth to Text Motivation for carrying out four months of messages adequate feeding practices and age of the child on the phone clarification of doubts on their (three implementation. messages)

*Awareness-raising on the importance of prenatal control and cognitive skills for child growth and development (60 minutes each session).

${ }^{*} 30$ minutes each session.

Scale. ${ }^{23}$ This tool inquires whether mothers perceive the signals (hunger or satiety) a baby younger than six months communicates during feeding and whether 
they are early, active or late. It includes two items: "If your child is hungry..." and "If your child is satiated...", followed by 10 phrases related to hunger signals and eight phrases for satiety signals. The answers are rated in a five-point Likert scale, where one means never and five means always. The sum of the answers was categorized as low (18-45), moderate (46-66) and high (67-90). Cronbach's alpha value obtained from this scale was 0.72 .

To assess feeding practices, the following questions were asked: "For how long did you exclusively breastfeed your child?" and "At what age did your child start feeding on bottle formula?"24 To measure maternal perception of infant's weight, the item "I think my child is..." was formulated, with the following response options: low weight, somewhat underweight, more or less with correct weight, somewhat overweight and overweight. ${ }^{25}$ Adequate perception was considered when the maternal response agreed with the child's nutritional status at the time of evaluation. Underestimating or overestimating weight was considered when the mother perceived weight as being lower or higher than the nutritional status the child really had, respectively.

Data were analyzed with the statistical program Statistical Package for the Social Sciences (SPSS), version 20. Descriptive statistics were obtained for sociodemographic variables (mother-child). To find out the normality of data, the Shapiro-Wilk test was applied; data showed a non-parametric distribution. For qualitative variables, the chi-square test and Fisher's exact test were used, and for quantitative variables, Mann-Whitney's U-test; statistical significance was considered with a $p$-value $<0.05$.

\section{Results}

At the beginning of the intervention, no significant differences were observed in the sociodemographic characteristics of the pregnant women, both from the $I G$ and the CG, except for the occupation (Table 2). Significant differences were identified in participants' postpartum BMI (26.55 in the CG and 23.95 in the IG, $p=0.043$ ) and in infants' BMI/age Z-score four months after birth, which was higher in the CG than in the IG $(p=0.034)$.

When the results of the variables of interest were compared at four months postpartum, women in the IG were observed to practice exclusive breastfeeding in a higher proportion than those in the CG (41.70 and $23.30 \%$, respectively). Regarding the cognitive
Table 2. Mothers and infants sociodemographic characteristics

\begin{tabular}{|l|c|c|c|}
\hline & $\begin{array}{c}\text { Control group } \\
(\mathrm{n}=30)\end{array}$ & $\begin{array}{c}\text { Intervention } \\
\text { group } \\
(\mathrm{n}=30)\end{array}$ & $p$ \\
\hline $\begin{array}{l}\text { Memographic characteristics } \\
\text { Number of }\end{array}$ & $27.50(20-40)$ & $27.50(19-38)$ & $0.812^{\mathrm{a}}$ \\
\hline $\begin{array}{l}\text { Nuildren } \\
\text { che }\end{array}$ & $3(1-5)$ & $2(1-5)$ & $0.179^{\mathrm{a}}$ \\
\hline
\end{tabular}

children

Marital status, $\mathrm{n}(\%)$

\begin{tabular}{|c|c|c|c|}
\hline With partner & $25(83.30)$ & $28(93.30)$ & \multirow[t]{2}{*}{$0.212^{c}$} \\
\hline No partner & $5(16.70)$ & $2(6.70)$ & \\
\hline \multicolumn{4}{|l|}{ Education, n (\%) } \\
\hline Basic & $5(16.70)$ & $4(13.30)$ & \multirow[t]{3}{*}{$0.676^{t}$} \\
\hline High school & $17(56.60)$ & $20(66.70)$ & \\
\hline $\begin{array}{l}\text { Higher } \\
\text { education }\end{array}$ & $8(26.70)$ & $6(20.00)$ & \\
\hline \multicolumn{4}{|c|}{ Occupation, n (\%) } \\
\hline Homemaking & $22(73.30)$ & $14(46.70)$ & \multirow[t]{2}{*}{$0.044^{b}$} \\
\hline Paid job & $8(26.70)$ & $16(53.30)$ & \\
\hline
\end{tabular}

Infant gender, n (\%)

\begin{tabular}{|c|c|c|}
\hline Female & $15(50.00)$ & $15(50.00)$ \\
\hline Male & $15(50.00)$ & $15(50.00)$ \\
\hline
\end{tabular}

Maternal anthropometric characteristics

Pre-gestational $\quad 69(45.00-85.00) \quad 65.00(54.00-96.00) \quad 0.906^{a}$ weight $(\mathrm{kg})$

$\begin{array}{llll}\text { GWG }(\mathrm{kg}) \quad & 9(4-12) \quad 0.096^{\mathrm{a}}\end{array}$ Current weight (kg) 71.00 (56.00-92.00) 66.00 (57.00-80.00) $0.030^{\mathrm{a}}$ Height $(m) \quad 1.64(1.50-1.70) \quad 1.66(1.54-1.77) \quad 0.091^{\text {a }}$ $\begin{array}{lll}\text { Current BMI } \quad 26.55(19.53-35.00) & 23.95(20.80-30.12) & 0.043^{a}\end{array}$ Nutritional status, $\mathrm{n}(\%)$

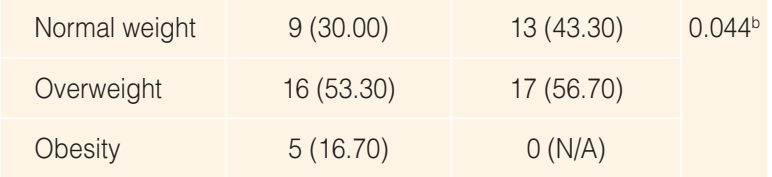

Infant anthropometric characteristics
$\begin{array}{llll}\text { Birth weight }(\mathrm{kg}) \quad 3.50(2.50-4.00) & 3.75(2.50-5.00) & 0.100^{\mathrm{a}}\end{array}$ Birth length $(\mathrm{kg}) \quad 50.00(45.00-54.00) 50.00(45.00-59.00) \quad 0.737^{\mathrm{a}}$ $\begin{array}{llll}\text { Current weight }(\mathrm{kg}) & 6.45(3.30-9.00) & 5.20(4.20-7.80) & 0.038^{\mathrm{a}}\end{array}$ Current length $(\mathrm{cm}) 62.00$ (48.00-70.00) 62.00 (55.00-66.00) $0.806^{\mathrm{a}}$ $\begin{array}{llll}\text { BMI-for-age z-score } 2.04(-2.38-3.85) & 0.40(-1.78-2.02) & 0.034^{a}\end{array}$ Values are expressed as the mean (range) or $\mathrm{n}(\%)$. ${ }^{a}$ Mann-Whitney's U-test. ${ }^{b}$ Chi-square test. 'Fisher's exact test. $\mathrm{GWG}=$ gestational weight gain, $\mathrm{BMI}=$ body mass index . 
Table 3. Intergroup comparison of variables of interest

\begin{tabular}{|c|c|c|c|c|c|}
\hline \multirow[t]{2}{*}{ Variable } & \multicolumn{2}{|c|}{ Control group } & \multicolumn{2}{|c|}{ Intervention group } & \multirow[t]{2}{*}{$\mathrm{p}$} \\
\hline & $n$ & $\%$ & $n$ & $\%$ & \\
\hline $\begin{array}{l}\text { Feeding practice } \\
\text { Exclusive breastfeeding } \\
\text { Bottle-feeding }\end{array}$ & $\begin{array}{l}14 \\
16\end{array}$ & $\begin{array}{l}23.30 \\
26.70\end{array}$ & $\begin{array}{c}25 \\
5\end{array}$ & $\begin{array}{c}41.70 \\
8.30\end{array}$ & $0.003^{a}$ \\
\hline $\begin{array}{l}\text { Maternal perception of child weight status } \\
\text { Adequate } \\
\text { Underestimates/overestimates }\end{array}$ & $\begin{array}{c}8 \\
22\end{array}$ & $\begin{array}{l}26.70 \\
73.30\end{array}$ & $\begin{array}{c}23 \\
7\end{array}$ & $\begin{array}{l}76.70 \\
23.30\end{array}$ & $0.001^{a}$ \\
\hline $\begin{array}{l}\text { Perception of hunger/satiety signals } \\
\text { High } \\
\text { Poor/moderate }\end{array}$ & $\begin{array}{c}1 \\
29\end{array}$ & $\begin{array}{c}3.30 \\
96.70\end{array}$ & $\begin{array}{c}25 \\
5\end{array}$ & $\begin{array}{l}83.30 \\
16.70\end{array}$ & $0.001^{b}$ \\
\hline $\begin{array}{l}\text { Infants' nutritional status } \\
\text { Low weight } \\
\text { Normal } \\
\text { Overweight } \\
\text { Obesity }\end{array}$ & $\begin{array}{c}1 \\
10 \\
11 \\
8\end{array}$ & $\begin{array}{l}3.30 \\
33.30 \\
36.70 \\
26.70\end{array}$ & $\begin{array}{c}0 \\
24 \\
5 \\
1\end{array}$ & $\begin{array}{c}0 \\
80.00 \\
16.70 \\
3.30\end{array}$ & $0.002^{\mathrm{a}}$ \\
\hline
\end{tabular}

${ }^{a}$ Chi-square test. bFisher's exact test.

Table 4. Intergroup comparison of maternal feeding practices according to maternal perception of children weight status and hunger and satiety signals

\begin{tabular}{|c|c|c|c|c|c|c|c|c|c|c|c|}
\hline \multirow[t]{3}{*}{ Group } & \multirow[t]{3}{*}{ Feeding practices } & \multicolumn{5}{|c|}{ Maternal perception of child weight status } & \multicolumn{5}{|c|}{ Maternal perception of hunger-satiety signals } \\
\hline & & \multicolumn{2}{|c|}{ Adequate } & \multicolumn{2}{|c|}{$\begin{array}{l}\text { Underestimates } \\
\text { or overestimates }\end{array}$} & \multirow[t]{2}{*}{ p } & \multicolumn{2}{|c|}{ High } & \multicolumn{2}{|c|}{ Poor or moderate } & \multirow[t]{2}{*}{ p } \\
\hline & & $n$ & $\%$ & $n$ & $\%$ & & $\mathrm{n}$ & $\%$ & $\mathrm{n}$ & $\%$ & \\
\hline \multirow[t]{2}{*}{ CG } & Exclusive breastfeeding & 3 & 10.00 & 11 & 36.70 & \multirow[t]{2}{*}{$0.426^{a}$} & 0 & 0.00 & 14 & 46.70 & \multirow[t]{2}{*}{$0.533^{a}$} \\
\hline & Bottle-feeding & 5 & 16.60 & 11 & 36.70 & & 1 & 3.30 & 15 & 50.00 & \\
\hline \multirow[t]{2}{*}{ IG } & Exclusive breastfeeding & 19 & 63.34 & 6 & 20.00 & \multirow[t]{2}{*}{$0.232^{\mathrm{a}}$} & 25 & 83.30 & 0 & 0.00 & \multirow[t]{2}{*}{$0.009^{a}$} \\
\hline & Bottle-feeding & 4 & 13.30 & 1 & 3.40 & & 0 & 0.00 & 5 & 16.70 & \\
\hline
\end{tabular}

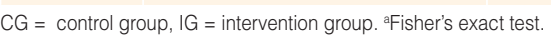

variables, CG mothers were more likely to underestimate or overestimate their children's weight than IG mothers (73.30 vs. $23.30 \%$ ); in addition, they poorly perceived hunger and satiety signals ( 96.70 vs. $16.70 \%$ ). Finally, IG infants had a higher percentage of normal weight $(80.00 \%)$ than CG children $(63.40 \%)$. All the results showed differences with statistical significance, $p<0.05$ (Table 3). In addition, IG mothers showed a high percentage of perceptive feeding $(83.30 \%)$ and greater practice of exclusive breastfeeding than $C G$ mothers $(p=0.009)$ (Table 4).

\section{Discussion}

In this study, a prenatal educational intervention in pregnant women was found to have an impact on the child's nutritional status, when it was corroborated four months after birth. Guidance on the benefits of exclusive breastfeeding, techniques for expressing and storing breast milk, among other aspects, apparently influenced the decision to exclusively breastfeed for longer than when no more extensive training was received on these practices, a result that is consistent with those of previous studies. ${ }^{9,26,27}$

It is important noting that the literature that addresses the perception of child weight status together with exclusive breastfeeding is quite limited, but when mothers are sensitive to perceiving their children's weight, they have been observed to choose healthier foods and to establish appropriate feeding routines. ${ }^{7,12,14}$ In this study, pregnant women who received advice on how to identify the correct weight of their 
future children and to clarify myths about it in infants were more able to estimate the nutritional status of their children at four months of age. These findings suggest the importance of accompaniment and guidance by health personnel to achieve that mothers adequately assess the growth and development of their children since they are born. ${ }^{13}$

Regarding the maternal perception of hunger and satiety signals, IG mothers perceived these signals with higher intensity, which was associated with exclusive breastfeeding. This is consistent with randomized clinical trials ${ }^{8-10}$ that show that responsive mothers were more likely to use feeding practices based on structure, establishment of limits and consistent feeding routines.

Finally, children's weight at birth did not show significant differences in both groups; however, at four months of age, more IG infants with adequate weight and no overweight were observed with regard to those of the CG. Therefore, providing cognitive tools to expectant mothers during pregnancy can have an impact on health-promoting behaviors for them and their children.

This is the first time that three cognitive concepts are studied together in Mexican future mothers to assess their effect on the nutritional status of the infant child, which apper to be promising for child weight control after birth. However, further research is required within different socioeconomic contexts, with representative samples and longer follow-up periods, to confirm the results herein presented.

\section{Conclusions}

It was possible to determine that the prenatal educational intervention had an effect on infants nutritional status, in whom obesity is already a health problem in Mexico. This research shows preliminary evidence of the importance of studying maternal cognitions in pregnant women in order to improve nutritional conditions in children at early childhood.

\section{Acknowledgements}

To Programa de Fomento y Apoyo a Proyectos de Investigación, PROFAPI 2015, for the funding assigned for this research.

\section{Conflict of interests}

None.

\section{Funding}

Funding was received from Programa de Fomento y Apoyo a Proyectos de Investigación, PROFAPI 2015, granted by Universidad Autónoma de Sinaloa.

\section{Ethical disclosures}

Protection of human and animal subjects. The authors declare that the procedures that were followed adhered to the ethical standards of the responsible committee for experimentation on human beings and were in agreement with the World Medical Association and the Declaration of Helsinki.

Confidentiality of data. The authors declare that they followed the protocols of their work center on the publication of patient data.

Right to privacy and informed consent. The authors obtained informed consent from the patients or subjects referred to in the article. This document is in the possession of the corresponding author.

\section{References}

1. Organización Mundial de la Salud [Internet]. Switzerland: Datos y cifras de obesidad infantil 2019; 2020.

2. Rivera JA, De Cossío T, Pedraza LS, Aburto TC, Sánchez TG, Martorell R. Childhood and adolescent overweight and obesity in Latin America: a systematic review. Lancet Diabetes Endocrinol. 2014;2:321-332.

3. Sanders RH, Han A, Baker JS, Cobley S. Childhood obesity and its physical and psychological co-morbidities: a systematic review of Australian children and adolescents. Eur J Pediatr. 2015;174:715-746.

4. Simmonds M, Llewellyn A, Owen CG, Woolacott N. Predicting adult obesity from childhood obesity: a systematic review and meta-analysis. Obes Rev. 2016;17:95-107.

5. Moreno-Villares J, Collado MC, Larqué E, Leis-Trabazo MR, Sáenz-de-Pipaon M, Moreno-Aznar LA. Los primeros 1000 días: una oportunidad para reducir la carga de las enfermedades no transmisibles. Nutr Hosp. 2019;36:218-232.

6. Haines J, Haycraft E, Lytle L, Nicklaus S, Kok FJ, Merdji M, et al. Nurturing Children's healthy eating: position statement. Appetite. 2019;137:124-133

7. Harrison M, Brodribb W, Davies PSW, Hepworth J. Impact of maternal infant weight perception on infant feeding and dietary intake. Matern Child Health J. 2018;22:1135-1145.

8. Paul IM, Savage JS, Anzman-Frasca S, Marini ME, Beiler JS, Hess LB, et al. Effect of a responsive parenting educational intervention on childhood weight outcomes at 3 years of age: the INSIGHT randomized clinical trial. JAMA. 2018;320:461-468.

9. Savage JS, Birch LL, Marini M, Anzman-Frasca S, Paul IM. Effect of the INSIGHT responsive parenting intervention on rapid infant weight gain and overweight status at age 1 year: a randomized clinical trial. JAMA Pediatr. 2016;170:742-749.

10. Kim SK, Park S, Oh J, Kim J, Ahn S. Interventions promoting exclusive breastfeeding up to six months after birth: A systematic review and meta-analysis of randomized controlled trial. Int J Nurs Stud. 2018;80:94-105.

11. Mennella JA, Papas MA, Reiter AR, Stallings VA, Trabulsi JC. Early rapid weight gain among formula-fed infants: Impact of formula type and maternal feeding styles. Pediatr Obes. 2019;14:e12503.

12. Ramírez-Pastore L, Gotz S, Sequera VG, Riera J, Brunilde P, Vera N, et al. Percepción materna del estado nutricional de sus hijos que acuden a un consultorio pediátrico, Asunción, 2018. Pediatr. 2018;45:217-222.

13. Kim LP, Mallo N. Maternal perceptions of self-weight and child weight may influence milk choice of participants in the Special Supplemental Nutrition Program for Women, Infants, and Children (WIC). J Obes. 2019;3654728.

14. Zaragoza-Cortés J, Trejo-Osti LE, Ocampo-Torres M. Impact of a complementary feeding intervention and mother's perceptions of child weight status in infants. Nutr Hosp. 2019;36:282-289. 
15. Blake-Lamb TL, Locks LM, Perkins ME, Woo Baidal JA, Cheng ER, Taveras EM. Interventions for childhood obesity in the first 1,000 days a systematic review. Am J Prev Med. 2016; 50:780-789.

16. Trejo-Ortiz P, Ahumada-Saucedo J. Factores asociados con la percepción materna del peso corporal del hijo: una revisión sistemática. Santiago VLIR. 2017;222-233.

17. Manikam LL, Lingam R, Lever I, Alexander E, Chidi A, Milner Y, et al. Complementary feeding practices for South Asian young children living in high-income countries: a systematic review. Nutrients. 2018;10:1676.

18. Eisenberg CM, Sánchez-Romero LM, Rivera-Dommarco, JA, Holub CK, Arredondo EM, Elder JP, et al. Interventions to increase physical activity and healthy eating among overweight and obese children in Mexico. Salud Publica Mex. 2013;55:441-446.

19. World Medical Association. World Medical Association Declaration of Helsinki ethical principles for medical research involving human subjects. JAMA. 2013;310:2191-2194.

20. Aristizábal-Hoyos GP, Blanco-Borjas DM, Sánchez-Ramos A, Ostiguín-Meléndez RM. El modelo de promoción de la salud de Nola Pender. Una reflexión en torno a su comprensión. Enferm Univ. 2011;8:16-23.
21. Organización Mundial de la Salud [Internet]. Switzerland: Dieta, ejercicio o ambos para prevenir el aumento excesivo de peso en el embarazo; 2020.

22. Organización Mundial de la Salud [Internet]. Switzerland: Patrones de crecimiento infantil; 2020.

23. Huges SO, Power TG. Parenting influences on appetite and weight. En: Lumeg JC, Fisher JO, editores. Pediatric food preferences and eating behaviors. Reino Unido: Academic Press; 2018.

24. Organización Mundial de la Salud [Internet]. Switzerland: Indicadores para evaluar las prácticas de alimentación del lactante y del niño pequeño; 2020.

25. Flores-Peña Y, Aguado-Barrera ME, Cerda-Flores RM, Cortés-Gutiérrez El, Dávila-Rodríguez MI. Percepción materna del peso del hijo y de niños no emparentados menores de un año. Aten Primaria. 2016;48:579-585.

26. Lewkowitz AK, Raghuraman N, López JD, Macone GA, Cahill AG. Infant feeding practices and perceived optimal breastfeeding interventions among low-income women delivering at a baby-friendly hospital. Am J Perinatol. 2019;36:669-677.

27. Kassianos AP, Ward E, Rojas-Garcia A, Kurti A, Mitchell FC Nostikasari D, et al. A systematic review and meta-analysis of interventions incorporating behavior change techniques to promote breastfeeding among postpartum women. Health Psychol Rev. 2019;13:344-372. 